\title{
Coordinative Practices and Information Interaction Performance in Distributed Work
}

\author{
Heljä Franssila \\ Tampereen yliopisto \\ helja.franssila@gmail.com
}

DI, YTK Heljä Franssilan informaatiotutkimuksen ja interaktiivisen median alaan kuuluva väitöskirja Coordinative Practices and Information Interaction Performance in Distributed Work (Koordinaatiokäytännöt ja informaatiovuorovaikutuksen suorituskyky) tarkastettiin 27.10.2017 Tampereen yliopistossa. Vastaväittäjänä toimi Reader, Dr Mark Perry (Brunell University London) ja kustoksena dosentti, yliopistonlehtori Sanna Talja (Tampereen yliopisto). Väitöskirja on julkaistu sarjassa Acta Universitatis Tamperensis ja se on luettavissa myös Tampereen yliopiston Tampub-julkaisuarkistossa osoitteessa http://urn.fi/URN:ISBN:978-952-03-0561-1

Asiasanat: hajautettu työ; koordinointi; informaatiokäyttäytyminen; suorituskyky

In this audience, there's plenty of people both from Tampere and Helsinki areas. During recent years, both in Tampere and in Helsinki two big channels and the process of making them ready has been of great common interest. The one in Tampere was building of Rantatunneli (the longest road tunnel in Finland), and the one in Helsinki is Länsimetro, (the western extension of metro in the metropolitan area). The performance of collaborative construction process of Rantatunneli has been a great success - and Länsimetro has been a great disaster. When comparing these two huge projects requiring collaboration, a strong candidate as a root cause for the performance differences has been the methods of coordination applied in the complex, collaborative effort. Joint effort between various collaboration parties 
has been coordinated differently in these two cases. The consequences of better and worse coordination method selections had been in societal level huge. Rantatunneli is ready and in use, Länsimetro years delayed.

The topic of my dissertation is coordination in distributed work. What is coordination? Coordination is about how to orchestrate interdependent work efforts into a flow of activities that produces a desired end product in time. This dissertation study analyzed ways of doing collaborative work together, in particular when the collaborators can't share the same place and same time when performing their interdependent work duties.

\section{Coordination matters}

While coordination problems may manifest in a company and societal level as performance losses, coordination impacts work performance also in individual level in everyday work. My dissertation research process started from a recurrent observation that I made when studying new information technologies and work organizations. Although there are plenty of information technological devices and communication channels available to support shared work efforts and interaction between collaborators, certain problems in work persist. Nowadays, nearly any discussion of the quality of working life and work performance issues in particular in information intensive work contexts refers more or less to the issues of information interactions in work. Constant themes raised relate to difficulties to find, get and mobilize information as a shared resource that is needed in work. The experiences of hurry, constant interruptions and message overflow are common (e.g. Franssila, Okkonen, \& Savolainen, 2014; Mark, Gudith, \& Klocke, 2008). Many of us relate these symptoms to the unquestioned, dysfunctional practices of communication and collaboration. Difficulties to orchestrate interdependent work duties manifest as inadequacies in information access and availability in individual work. This observation is astonishing compared to the original performance enhancement goals that had motivated the adoption of information technologies into work processes.

For me, a driving force to start and fulfill a research process is understanding an issue in the real world that needs to be changed or fixed, and which affects many people or has relevance to many. The issue I tried to understand and explain in this dissertation study was the information interaction in distributed work, which more or less seems to be broken at the moment.

The goal of the dissertation study was to understand and explain how the work performance of a single worker participating in collaborative efforts is influenced by the nature of coordination. Coordination can be accomplished in many ways and applying a variety of mechanisms (e.g. Okhuysen \& Bechky, 2009; Schmidt, 
2011). Coordination was defined in this study as practical management of interdependencies between goals, activities, and resources of work that bind individual collaborators. Coordinative practices are communicative and information interaction activities which fulfill variety of coordination needs. Because coordinative practices always contain some form of communication and information management, the possibilities of ICTs as part of coordinative practices are critical.

\section{Coordination as a research field}

Coordination as a phenomenon is of multi-disciplinary interest in academic research. Needs, ways and methods to coordinate collaborative work and support coordination are in the research agenda both in management, behavioral and information sciences and information systems (IS) research, and in particular in research traditions of computer supported co-operative work (CSCW) and human computer interaction (HCI). Coordination is very topical as a research theme at the moment, because more and more work can or need to be executed remotely and without need for collaborators to be co-located. Need to smoothly distribute and redistribute work execution, often over time zone differences requires efficient coordination. Also new possibilities that innovations in interface interaction methods and overall connectivity require reconsideration as means of coordination.

Partly because of the research and innovation funding reasons, computer supported co-operative work research is often focused around certain applications to be renewed or on certain quite clearly delineated workflows or activities present in certain work context. Introduction of new application contains a promise of work performance enhancement for that particular activity that it is designed to support. The mere introduction of new application into the repertoire of communication and interaction options does not guarantee work performance development gains. Part of the reason for unfulfilled expectations regarding new applications can be, that there has not been concrete enough and explicit measures to show how and why work performance in the level of each individual worker potentially enhances via utilization of new application. That is why renewal and implementation process need to cover also the practices and conventions how interrelated activities of collaborators will be coordinated in behavioral level, and why this might make sense and provide trade-offs for an individual worker, too.

The trade-offs and benefits that new technologies provide for individual worker as a participant of coordinated, collaborative effort are issues that Information Systems research has traditionally touched in the studies of technology adoption and information systems success. However, the viewpoint has mainly been in understanding why certain technology gets adopted or not both in individual and collecti- 
ve level. The concrete benefits that new information technology and the associated new coordinative practice can provide for individual worker are often left unspecified - and even ways to measure performance effects are absent.

\section{Application of lean management approach to information interaction performance}

In this dissertation study the concept of waste from lean management was applied as a conceptual tool to evaluate information interaction performance (see Hicks, 2007). Waste is defined as any activity that consumes resources but does not create value. Waste refers to effort and time lost without progress in activity at hand. It was found out in the dissertation study, that inappropriate coordinative practices hamper the work performance of a worker, by wasting time and energy into unnecessary activities of searching and repairing information needed in task execution. In this dissertation study, generation and also avoidance of waste activities related to information were observed in four different distributed work context - in chemicals production, in technical support centers, in telecommunications business services and in security service. The study shows how difficult and slow it is to provide technical support if the solution database is incomplete and basic characteristics of the faulty machine are difficult to obtain. Study shows also how error-prone is shiftchange situation in continuous chemicals production or in security service if details of activities executed in previous shift are not documented in permanent format or information about changes in situation in the premises are difficult to obtain. On the other hand, study showed how complex business collaborations can be fluently executed with help of simple mobile technologies.

The topic of my dissertation research is coordination of distributed work, but the viewpoint is in the level of performance of a single work role holder. Coordination is secondary but necessary work, that need to be done so that individual contributions can fit together in smooth manner and work activity produces what it is expected to produce. Coordination serves several functions in collaborative efforts. Coordination is needed for example for ordering, sequencing and timing of interdependent activities. Coordination is needed also for expressing and acknowledging status of the common object of work, shared resources and activity processes. 


\section{Coordination success and information interaction performance}

In theory coordination would be very straightforward to implement, if all the interdependences between goals, activities and resources that realize in the work of a certain work role would be well-known. Everyone involved knows perfectly how ones activities are related to other activities, which resources are needed in each point of the value creation and how those resources are created, maintained and allocated. This is not the situation. Many of the work domains and value-creation chains that constitute the work context of an individual work role holder contain complex set of interdependencies of various sort. The set can contain interdependencies that are obvious, well-known, recurring often and even predictably, but also interdependencies that are difficult to observe, occurring sporadically and ambiguous.

Dissertation study analysed also the impacts of richness of technological affordances, social capital and spatio-temporal dispersion on the coordinative practices. Technological affordances refer to possibilities that certain technology provides for the actor - what that technology affords one to do. Technological affordances are interpretations actors make about the potential of certain technology to support one's goals. Social capital refers to valuable, intangible resources that social structures can provide for collaborators to support shared conduct of affairs. Spatio-temporal dispersion refers to the level of geographical distance and time zone difference between collaborators. The results of the study show that in successful coordinative practices a varied set of technologies are utilized and social capital enhances coordination.

The practical means of coordination can vary also, and here the critical relationship between coordination and information interaction performance becomes evident. Coordination can be accomplished via various means and technologies. This dissertation study sheds light to the performance enhancement potential that resides in better observing and understanding coordination needs and managing them more consciously and systematically. If there is an interdependence between activities or resources that affects certain task accomplishment often and from case to case in similar fashion, it makes sense to apply a coordination mechanisms that is formalized. It does not make sense to invent wheel several times. On the contrary, it does not make sense to try to formalize a coordination practice too far, if it is unclear how often certain need to coordinate the interdependence will occur.

This dissertation illustrates, how inexplicit the production design of many services is, when the service product is mainly based on informational resources and the product is created via distributed collaborative work. The practical understanding about the recurring needs for information that is created by someone else and in different moment of time than the current utilization situation is weak and not 
supported enough by coordination artifacts and agreements to maintain shared information resources. Better understanding and design of coordinative practices provides performance enhancement possibilities worth exploring.

\section{References}

Franssila, H., Okkonen, J., \& Savolainen, R. (2014). Tietotyön informaatioergonomian arviointi- ja kehittämismenetelmä. Tampere: Tampereen yliopisto. http://urn. fi/URN: ISBN: 978-951-44-97001 (luettu 12.12.2017)

Hicks, B. J. (2007). Lean information management: Understanding and eliminating waste. International Journal of Information Management, 27(4), 233-249. https://oadoi .org/10.1016/j. ijinfomgt. 2006.12.001

Mark, G., Gudith, D., \& Klocke, U. (2008). The Cost of Interrupted Work: More Speed and Stress. Teoksessa Proceedings of the SIGCHI Conference on Human Factors in Computing Systems (ss. 107110). New York, NY, USA: ACM. https://oadoi.org/10.1145/1357054.1357072

Okhuysen, G. A., \& Bechky, B. A. (2009). 10 Coordination in Organizations: An Integrative Perspective. Academy of Management Annals, 3(1), 463-502. https://oadoi .org/10.1080/19416520903047533

Schmidt, K. (2011). Cooperative Work and Coordinative Practices : Contributions to the Conceptual Foundations of Computer-Supported Cooperative Work (CSCW). London: Springer. 